Su ile hazırlanan zeytin yaprağı özütünün ratlarda streptozotosin kaynaklı oksidatif stres ve lipit peroksidasyonu üzerine etkileri

\author{
Fatma GÜR ${ }^{1}$, Ahmet Gökhan AĞGÜL ${ }^{2}$, Mine GÜLABOĞLU ${ }^{3}$
}

ÖZET: Bu çalışmada, Streptozotosin'in (STZ) neden olduğu diyabetik ratlarda su içinde hazırlanan zeytin yaprağı özütünün (OLE) antidiyabetik ve antioksidatif etkilerinin araştırması amaçlanmıştır. Çalışmamızda Atatürk Üniversitesi Tıbbi Uygulama ve Araştırma Merkezi (ATADEM)'den temin edilen ve ağırlıkları 200-215 g arasında değişen toplam 25 adet Albino Wistar erkek rat kullanıldı. Ratlar Kontrol, $0.5 \mathrm{~g} \mathrm{~kg}^{-1}$ OLE, $40 \mathrm{mg} \mathrm{kg}{ }^{-1} \mathrm{STZ}, 0.25 \mathrm{~g} \mathrm{~kg}^{-1}$ OLE + STZ ve $0.5 \mathrm{~g} \mathrm{~kg}^{-1} \mathrm{OLE}+\mathrm{STZ}$ olmak üzere beş gruba ayrıldı. 14 günlük OLE uygulama sonrası ratların karaciğer dokuları süperoksit dismutaz (SOD), glutatyon peroksidaz (GPx), glutatyon S-transferaz (GST) aktivitelerinin ve malondialdehit (MDA) seviyelerinin belirlenmesi için alındı. Kan örnekleri ise alanin transaminaz (ALT), aspartat transaminaz (AST) ve alkalen fosfataz (ALP) biyokimyasal parametrelerinin ve ek olarak glikoz seviyelerinin belirlenmesi için alındı. İstatistiksel analizler SPSS 20.0 yazılım programı kullanılarak ANOVA testi ile belirlendi. STZ ile birlikte OLE'nin iki farklı dozda oral yoldan verilmesinden sonra, diyabetik grup ile karşılaştırıldığında OLE'nin her iki doz grubunda ALP, ALT ve AST düzeylerinde önemli düşüşler gözlenmiştir ( $\mathrm{p}<0.001)$. Ayrıca, sadece STZ verilen gruba kıyasla, STZ ile birlikte OLE uygulanan gruplarda SOD, GPx ve GST aktivitelerinde anlamlı bir artışla birlikte MDA, ALT, AST ve ALP

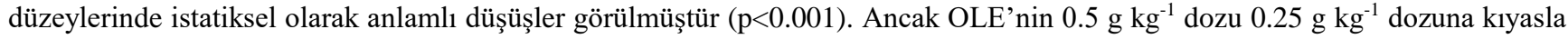
daha etkili olmuştur. Sonuç olarak, elde edilen in-vivo veriler, suda hazırlanan OLE'nin oksidatif stresin kisıtlanması ve antioksidan aktivitelerin güçlendirilmesi sayesinde bir anti-diyabetik etkiye sahip olabileceğini göstermiştir.

Anahtar Kelimeler: Streptozotosin, Diabetes Mellitus, Zeytin yaprağı özütü, antioksidan, rat

\title{
Effects of olive leaf extract prepared in water on streptozotocin-induced oxidative stress and lipid peroxidation in rats
}

\begin{abstract}
The present study aims to investigate antidiabetic and antioxidative effects of olive leaf extract (OLE) prepared in water in Streptozotocin (STZ)-induced diabetes in experimental rats. 25 Albino Wistar male rats, each weighing 200-215 g, were used for the experiment after being obtained from Medical Experimental Application and Research Centre (ADEM). The animals were divided into five groups: Control Group, $0.5 \mathrm{~g} \mathrm{~kg}^{-1}$ OLE Alone Group, $40 \mathrm{mg} \mathrm{kg}^{-1} \mathrm{STZ}$ Alone Group, $0.25 \mathrm{~g} \mathrm{~kg}{ }^{-1} \mathrm{OLE}+\mathrm{STZ}$ Group (T1), and $0.5 \mathrm{~g} \mathrm{~kg}^{-1} \mathrm{OLE}+\mathrm{STZ}$ Group (T2). Following the application of OLE for fourteen days, the livers of the animals were dissected to determine the activities of superoxide dismutase (SOD), glutathione peroxidase (GPx), Glutathione S-transferases (GST) in addition to malondialdehyde (MDA) levels. Besides, their blood samples were obtained to investigate the biochemical parameters of alanine transaminase (ALT), aspartate transaminase (AST), and alkaline phosphatase (ALP) apart from glucose levels. Statistical analyses were performed via the ANOVA test using the SPSS 20.0 software program. After an oral administration of OLE in two different doses along with STZ, there was a significant decrease in ALT, AST and ALP levels of the animals in the high-dose group (T2: OLE+STZ) compared to the diabetic group (STZ) ( $p$ <0.001). After the administration of OLE with STZ in two different doses, there were significant changes in the ALT, AST and ALP levels of T1 and T2 Groups when compared to the diabetic group $(\mathrm{p}<0.001)$. Besides, compared to STZ Alone Group, the SOD, GPx and GST activities significantly increased while MDA, ALT, AST and ALP levels significantly decreased ( $\mathrm{p}<0.001$ ). However, $0.5 \mathrm{~g} \mathrm{~kg}^{-1}$ of OLE was more effective than was 0.25 $\mathrm{g} \mathrm{kg}^{-1}$. As a result, the in-vivo data showed that OLE dissolved in water could have an anti-diabetic effect by restricting oxidative stress and reinforcing antioxidant activities.
\end{abstract}

Keywords: Streptozotocin, Diabetes Mellitus, Olive Leaf Extract, Antioxidant, Rat

\footnotetext{
${ }^{1}$ Fatma GÜR (Orcid ID: 0000-0001-5983-1472), Department of Medical Services and Techniques, Health Services Vocational School, Atatürk University, Erzurum, Turkey

${ }^{2}$ Ahmet Gökhan AĞGÜL (Orcid ID: 0000-0003-0377-0388), Department of Biochemistry, Faculty of Pharmacy, Ağrı Ibrahim Çeçen University, Ağrı, Turkey

${ }^{3}$ Mine GÜLABOĞLU (Orcid ID: 0000-0002-3248-1502), Department of Biochemistry, Faculty of Pharmacy, Ataturk University, Erzurum, Turkey

*Sorumlu Yazar/Corresponding Author: Fatma GÜR; e-mail: fatmagur@atauni.edu.tr
}

ETIK KURUL ONAYI / ETHICS COMMITTEE APPROVAL: Bu makale yer alan hayvan deneyi “Atatürk Üniversitesi Rektörlüğü Hayvan Deneyleri Yerel Etik Kurulu tarafindan 22.04.2009 tarih ve B.30.2.ATA.0.22.02.00-208 sayıl1 yazısı ile etik kurallara uygun olduğu onaylanmıştır. 


\section{GíRiș}

21. yüzyılın en büyük sağlık sorunlarından biri olan diyabet, dünyada ölüme neden olan en yaygın 10 hastalık arasında yer almaktadır. Uluslararası Diyabet Federasyonu (IDF) tarafindan, 2017 yılında 20-79 yaşları arasında yaklaşık 4 milyon kişinin diyabet nedeniyle öldüğü ve bunun her sekiz saniyede bir ölüme tekabül ettiği bildirilmiştir. Ayrıca IDF 2017 raporuna göre, dünyada yaklaşık 425 milyon kişinin (20-79 yaş yetişkinlerin\% 8.8'i) şeker hastası olduğu belirtilmiştir. Bu eğilimin devam etmesi durumunda, 2045 yılında yaklaşık 629 milyon kişinin (yetişkinlerin \%10'u) şeker hastası olacağı rapor edilmiştir (Coşkunırmak 2018).

Diabetes mellitus (DM), hiperglisemi ile karakterize edilen metabolik bir hastalıktır. İnsülin salgılanmamasının, salgılanan insülinin etkisini göstermemesinin veya her iki durumun neden olduğu bu hastalık, başta göz, kalp, böbrek, kan damarları ve sinirler olmak üzere farklı organlarda uzun süreli hasar ve işlev bozukluğuna neden olmaktadır (Eidi ve ark., 2009, Tang ve ark., 2012, ADD 2014). Diyabet hastalığı sonucu ortaya çıkan birçok sorun vardır. Bunlardan bir tanesi de serbest oksijen radikallerinin neden olduğu hücre hasarı sonucu ortaya çıkan komplikasyonlardır (Tietz 1995, Dawn ve ark., 1996, Burtis ve Ashwood 1999).

Serbest radikaller, bir veya daha fazla sayıda eşleşmemiş elektron içeren moleküllerdir. Biyolojik sistemlerde serbest radikaller normal metabolik olayların seyrinde ve bazı yabancı maddelerin (ksenobiyotikler) metabolize edilmesi sırasında oluşabildiği gibi organizmanın radyasyon gibi dış etkenlere maruz bırakılmasıyla da meydana gelebilir. Bunlar kimyasal olarak oldukça aktiftirler ve ortamdaki diğer biyomoleküllere özellikle de nükleik asit, protein ve lipitlere bağlanarak onların biyolojik yapılarını oksitleyebilir ve metabolizmada olumsuz etkiler gösterebilirler. Organizmalar istenmeyen bu etkileri antioksidan sistemler ile yok etmektedir (Fantel 1996, Yanbeyi 1999, Temple 2000, Stadtman 2004).

Antioksidan aktivitesi ve kimyasal kompozisyon yönüyle zeytin meyvesi ve zeytinyağı ile ilgili çalışmalar yapılmıştır (Kritsakis 1998, Bouaziz ve ark., 2004, Bouaziz veSayadi 2005). Zeytin yaprakları, en yüksek antioksidan aktiviteye sahip doğal ürünlerdir ve içerdikleri fenolik bileşenler açısından sağlıklı beslenmenin vazgeçilmez bir unsurudur (Visioli ve ark., 2002, Jemai ve ark., 2009, El-Amin ve ark., 2013). Zeytin yaprakları başlıca flavonoidler, sekoiridoidler ve triterpenler olmak üzere üç farklı bileşik içerir. Zeytin yaprağının en etkili etken maddesi secoiridoid grubunun doğal bir ürünü olan oleuropeindir (Benavente-Garcia ve ark., 2000).

Ayrıca, zeytin yapraklarının da antidiyabetik ve antihipertansif bitkisel bir ilaç etkisine sahip olduğu bilinmektedir (Pereira ve ark., 2006). Zeytin yaprağı ile hazırlanan özütlerin antioksidan kapasitesi güçlü bir antioksidan olan hidroksitirosolin antioksidant etkisine yakın, C ve E vitaminin antioksidan etkisinden ise çok daha yüksek düzeyde olduğu rapor edilmiştir (Benavente-García ve ark., 2000, Benavente-Garcia ve ark., 2002). Yapılan çalışmalarda, su ile hazırlanan zeytin yaprağı özütünün (OLE) antidiyabetik ve antioksidan etkileri 8-10 hafta gibi uzun tedavi sürelerine bağlı olarak süperoksit dismutaz (SOD), glutatyon peroksidaz (GPx), glutatyon $\mathrm{S}$ transferaz (GST) aktiviteleri ve malondialdehit (MDA) seviyeleri ile araştırılmıştır.

Yapılan bu çalışmada, su ile hazırlanan OLE'nin sadece 2 haftalık tedavi sonrası ratlarda streptozotosin kaynaklı oksidatif stres ve lipit peroksidasyonu üzerine etkileri, ALT, ALP, AST, SOD, GPx ve GST aktiviteleri ve MDA seviyeleri dikkate alınarak araştırılmıştır.

\section{MATERYAL VE YÖNTEM}

Bu çalışmada yer alan hayvan deneylerinin "Atatürk Üniversitesi Rektörlüğü Hayvan Deneyleri 
Yerel Etik Kurulu tarafindan 22.04.2009 tarih ve B.30.2.ATA.0.22.02.00-208 sayıl1 yazıs1 ile etik kurallara uygun olduğu onaylanmıştır.

\section{Kimyasallar}

Streptozotosin (STZ, $\mathrm{C}_{8} \mathrm{H}_{15} \mathrm{~N}_{3} \mathrm{O}_{7}$; moleküler ağırlık 265.221 Da, CAS: 66395-18-4) SigmaAldrich, ABD'den temin edildi. Diğer kimyasallar analitik bir saflıkta Merck Chemicals, Almanya firmasından satın alındı ve herhangi bir işlem yapılmadan doğrudan kullanıldı.

\section{Hayvanlar ve beslenme}

$\mathrm{Bu}$ çalışma, Ulusal Sağlık Enstitüsü (NIH) Laboratuvar Hayvanlarının Bakımı ve Kullanımı Kılavuzu tarafından yayınlanan kriterler dikkate alınarak yapılmıştır. Bu çalışmada kullanılan ratlar, deney boyunca standart çevresel koşullar altında $\left(22 \pm 2{ }^{\circ} \mathrm{C}, 12\right.$ saat açı/kapalı 1şık döngüsü) özel kafeslerde tutuldular. OLE uygulama tedavileri de aynı dönemler içerisinde gerçekleştirildi. Tedavi boyunca hayvanlar ad libitum ile beslendiler (pellet diyeti ve su).

\section{STZ'ye bağlı diyabetin indüksiyonu}

Ratlarda 12 saat açlık sonrası $10 \mathrm{mM}$ soğuk sitrat tamponu içinde yeni hazırlanmış STZ (40 mg/kg) solüsyonunun intraperitoneal (i.p.) tek doz uygulaması sonrası diyabet geliştirildi. Uygulamadan yaklaşık 4 ila 6 saat sonra, öldürücü hipoglisemi nedeniyle ratlara 24 saat süreyle $\% 5.0$ dekstroz çözeltisi verildi. STZ uygulamasından 72 saat sonra, ölçülen kan glikoz seviyeleri (BGL'ler) ölçülerek 200 mg $\mathrm{dL}^{-1}$ 'nin üzerinde olan ve poliüri ve polidipsi semptomlarının geliştiği hayvanlar diyabetli kabul edildi (Macdonald 2008).

\section{OLE'nin hazırlanması}

OLE hazırlama metodu literatür çalışmaları dikkate alınarak bazı modifikasyonlar ile belirlendi. Bu çalışma için deney materyali olarak Türkiye'nin Doğu Karadeniz Bölgesi'ndeki Artvin iline bağlı Yusufeli ilçesinden taze zeytin yaprakları (Olea europae L.) toplanmıştır. Bu yapraklar temizlendikten ve oda sicaklığında kurutulduktan sonra, sıvı azotta bir havanda öğütülerek toz haline getirildi ve $22^{\circ} \mathrm{C}$ $\pm 1{ }^{\circ} \mathrm{C}$ sıcaklıkta kuru bir yerde saklandı. Elde edilen toz 3 saat boyunca sürekli karıştırılarak kaynatılarak su içinde art arda özümlendi. Daha sonra konsantre hale gelen öz, bir filtre kağıdından süzüldü. Süzüntü daha sonra $40-45{ }^{\circ} \mathrm{C}$ sıcaklıkta bir döner buharlaştırıcı yardımıyla vakum altında tutularak kalan çözücü nihai çözeltiden uzaklaştırıldı. Böylece, yüksek konsantrasyonlu ham özüt elde edildi (Baz 2014, Al-Attar veAlsalmi 2019).

\section{Kan şekeri ölçümü}

BGL'ler, STZ indüksiyonundan 72 saat sonra kuyruk veninden alınan kan örneklerinin haftalık aralıklarla Accu-Check Active glukometre belirlenerek ratların açlık kan şekeri ölçüldü. Seviyeler mg $\mathrm{dL}^{-1}$ cinsinden ifade edildi.

\section{Vücut ağırlı̆̆ı tayini}

Deney hayvanları başlangıçta tartıldı ve 200-220 g aralığında olduğu belirlendi. 14 gün tedavi uygulama süresince ratların ağırlıkları takip edildi.

\section{OLE uygulaması}

Hazırlanan OLE'nin uygulama dozları, ratların vücut ağırlığına bağlı olarak hesaplandı ve distile suda hazırlandı. Tüm dozlar $\left(0.25 \mathrm{~g} \mathrm{~kg}^{-1}\right.$ ve $\left.0.5 \mathrm{~g} \mathrm{~kg}^{-1}\right), 14$ gün süreyle günde bir defa olmak üzere 1.0 $\mathrm{mL}$ oral gavaj yoluyla uyguland. 


\section{Deneysel tasarım}

Deney için, 25 yetişkin erkek Wistar albino rat kullanıldı. Hayvanlar, aynı vücut ağırlı̆̆ına sahip ratlardan oluşan 5 gruba ayrıldı. Gruplar, bir tanesi kontrol grubu olmak üzere aşağıdaki şekilde kategorize edildi:

(i) Grup K (Kontrol): Sadece su verilen ratlardan oluşmuştur.

(ii) Grup OLE (0.5 $\left.\mathrm{g} \mathrm{kg}^{-1} \mathrm{OLE}\right): 0.5 \mathrm{~g} \mathrm{~kg}^{-1}$ dozunda özüt uygulanan ratlardan oluşmuştur. OLE ile literatür çalışmaları dikkate alınarak $0.5 \mathrm{~g} \mathrm{~kg}^{-1}$ dozun yüksek doz olduğu göz önüne alındığında, çalışmamızda bu grupta yüksek doz kullanıldı ve bu sayede hayvan israfını önlendi.

(iii) Grup D (STZ), diyabetik ratlardan oluşmuştur.

(iv) Grup T1 (0.25 g kg-1 OLE + STZ) vücut ağırlığına göre $0.25 \mathrm{~g} \mathrm{~kg}^{-1}$ dozunda özüt verilen diyabetik ratlardan oluşmuş tedavi grubudur.

(v) Grup T2 (0.5 g kg-1 OLE + STZ), vücut ağırlığına göre $0.5 \mathrm{~g} \mathrm{~kg}^{-1}$ dozunda özüt verilen diyabetik ratlardan oluşmuş tedavi grubudur.

\section{Biyokimyasal deneyler}

Biyokimyasal analizler yapmak amacıyla 14 gün OLE uygulaması sonrası deney gruplarından intrakardiak kan örnekleri alındı. Daha sonra tiopentalin yüksek dozda uygulaması sonucu tüm rat grupları ötanazi edildi ve akabinde tüm rat gruplarından karaciğer doku örnekleri alındı. Vakumlu normal biyokimya tüplerine alınan kan örnekleri 5-10 dakika arası oda sıcaklığında bekletildikten sonra 10 dakika boyunca 3000 rpm'de santrifüj edildi (Baz 2014). Ratların alanin transaminaz (ALT), aspartat transaminaz (AST) ve alkalen fosfataz (ALP) düzeylerinin belirlenmesinde serum örnekleri kullanılmış ve daha sonra Atatürk Üniversitesi Araştırma Hastanesinde Cobas c501 analizörü (Roche Ltd, İsviçre) ile analiz edilmiştir. Karaciğer doku örnekleri ise süperoksit dismutaz (SOD), glutatyon peroksidaz (GPx), glutatyon S transferaz (GST) aktiviteleri, malondialdehit (MDA) ve protein düzeylerinin belirlenmesinde kullanıldı.

Daha sonra karaciğer dokuları çıkarıldı ve hemen serum fizyolojik tuzlu su ile (\% $0.9 \mathrm{NaCl})$ yıkanarak çalışma gününe kadar $-80^{\circ} \mathrm{C}$ 'de muhafaza edildi. Deneysel çalışmada doku örnekleri sıvı azot ile toz haline getirildi. Doku örnekleri, MDA ve protein seviyeleri ile birlikte SOD, GST ve GPx aktivitelerini belirlemek için homojenize edildi. SOD, GST ve GPx aktiviteleri literatürde açıklanan prosedürler kullanılarak test edildi (Paglia veValentine 1967, Habig ve ark., 1974, Sun ve ark., 1988). MDA seviyesi Jain ve ark. tarafından açıklanan prosedür kullanılarak belirlendi (Jain ve ark., 1989). Ayrıca karaciğer doku örneklerinde bulunan toplam protein konsantrasyonu Bradford protein tayin metoduna göre belirlendi (Bradford 1976).

\section{İstatistiksel analiz}

İstatistiksel analizler SPSS ver. 20.0 yazılımı (SPSS Inc., Chicago, ABD) software programı kullanılarak yapıldı. Bütün ölçümlerde istatistiksel farklılıklar ve önem seviyeleri ANOVA testi ile belirlendi. Sonuçlar, rat gruplarındaki ölçümün ortalaması (ortalama \pm SD) olarak gösterildi. * diyabetik gruba (D) göre $\mathrm{p}<0.05$ seviyesinde anlaml, ${ }^{* *}$ diyabetik gruba (D) göre $\mathrm{p}<0.001$ seviyesinde anlaml kabul edildi. Çoklu karşılaştırmalarda LSD testi uygulandı (Baz 2014).

\section{BULGULAR VE TARTIŞMA}

$\mathrm{Bu}$ çalışmada, OLE tedavisinin STZ kaynaklı diyabetik ratlarda oksidatif stres ve lipit peroksidasyonu üzerine etkisinin belirlenmesi amaçlanmıştır. Bu kapsamda OLE'nin kan glikoz 
seviyeleri (BGL) üzerindeki etkileri, rat ağırlıklarına etkisi, biyokimyasal parametreler üzerine etkisi ve antioksidan enzim aktiviteleri araştırıldı.

OLE’nin kan glikoz seviyeleri (BGL) üzerindeki etkileri tüm çalışma gruplarında ölçülmüş, ancak bu seviyeler için önemli bir fark bulunamamıştır. Ayrıca OLE’nin rat ağırlıklarına etkisi takip edilmiştir. 14 günün sonunda, sağlıklı ratlara $\left(0.5 \mathrm{~g} \mathrm{~kg}^{-1} \mathrm{OLE}\right)$ kıyasla iki farklı özüt dozu $\left(0.25 \mathrm{~g} \mathrm{~kg}^{-1}\right.$ ve $0.5 \mathrm{~g} \mathrm{~kg}^{-}$ ${ }^{1}$ OLE+ STZ) verilen ratların vücut ağırlığındaki artış arasında önemli farklılıklar gözlenmedi. Tüm çalışma gruplarının karaciğer enzim seviyeleri, tedavi bittikten sonra ölçüldü ve serum ALP, ALT ve AST seviyeleri üzerindeki etkileri Çizelge 1'de gösterilmiştir.

Çizelge 1. Tüm çalışma grupları için ortalama ALP, ALT ve AST değerleri

\begin{tabular}{llcc}
\hline GRUPLAR & ALP $\left(\mathbf{U} \mathbf{~ m L}^{-1}\right)$ & ALT $\left(\mathbf{U} \mathbf{~ m L}^{-1}\right)$ & AST $\left(\mathbf{U} \mathbf{~ m L}^{-1}\right)$ \\
\hline Grup K & $253.08 \pm 34.46^{* *}$ & $54.71 \pm 6.12^{* *}$ & $157.70 \pm 18.48^{* *}$ \\
Grup OLE & $259.32 \pm 30.35^{* *}$ & $61.08 \pm 7.89^{* *}$ & $156.63 \pm 18.01^{* *}$ \\
Grup D & $530.69 \pm 50.28^{* *}$ & $108.81 \pm 11.82^{* *}$ & $299.31 \pm 30.64^{* *}$ \\
Grup T1 & $515.78 \pm 48.73^{* *}$ & $106.69 \pm 10.94^{* *}$ & $286.54 \pm 20.23^{* *}$ \\
Grup T2 & $502.53 \pm 46.10^{* *}$ & $90.34 \pm 8.86^{* *}$ & $257.18 \pm 28.93^{* *}$ \\
\hline
\end{tabular}

Tüm değerler ortalama $\pm \mathrm{SD}(\mathrm{n}: 5)$ olarak ifade edildi. *P $<0.05$ Grup D'ye kıyasla, **P $<0.001$ Grup D'ye kıyasla LSD çoklu karşılaştırma testlerinden önce gelen tek yönlü ANOVA. K: Kontrol; OLE: Yüksek doz OLE (0.5 g kg$\left.{ }^{-1}\right)$; D: Diyabetik; T1: Diyabetik + düşük doz OLE $\left(0.25 \mathrm{~g} \mathrm{~kg}^{-1}\right)$; T2: Diyabetik + yüksek doz OLE $\left(0.5 \mathrm{~g} \mathrm{~kg}^{-1}\right)$.

Çizelge 1 dikkate alındığında karaciğer ALP, ALT ve AST seviyelerinin, kontrol grubuna göre diyabetik ratlarda yükseldiği anlaşılmaktadır ( $\mathrm{p}<0.001)$. OLE'nin iki farklı dozda $\left(0.25 \mathrm{~g} \mathrm{~kg}^{-1} \mathrm{ve} 0.5 \mathrm{~g}\right.$ $\mathrm{kg}^{-1}$ ) oral yoldan verilmesini takiben Grup T1 ve T2'nin ALP, ALT ve AST düzeylerinde Grup D'ye kıyasla anlamlı düşüş gözlendi ( $\mathrm{p}<0.001)$. Öte yandan düşük doz OLE uygulamasına kıyasla yüksek doz OLE uygulaması sonrası, karaciğer enzim seviyelerindeki düşüşün istatistiki olarak daha anlamlı olduğu Çizelge 1'de gösterilmiştir.

OLE'nin rat karaciğer oksidan-antioksidan durumları üzerindeki etkilerini belirlemek amacıyla tüm grupların oksidan-antioksidan durumları OLE uygulaması sonrasında ölçülmüş ve belirlenen SOD, GPx ve GST antioksidan enzim aktiviteleri ve MDA seviyeleri Çizelge 2'de sunulmuştur.

Çizelge 2. Tüm çalışma grupları için ortalama SOD, GPx, GST ve MDA değerleri

\begin{tabular}{lcccc}
\hline GRUPLAR & $\begin{array}{c}\text { SOD } \\
\left(\mathbf{U} \mathbf{~ m g}^{-1} \text { protein }\right)\end{array}$ & $\begin{array}{c}\text { GPx } \\
\left(\mathbf{U} \mathbf{~ m g}^{-1} \text { protein }\right)\end{array}$ & $\begin{array}{c}\text { GST } \\
\left(\mathbf{U ~ m g}^{-1} \text { protein) }\right.\end{array}$ & $\begin{array}{c}\text { MDA } \\
\left(\mathbf{n m o l} \mathbf{~ m g}^{-1} \mathbf{p r o t e i n}\right)\end{array}$ \\
\hline Grup K & $25.65 \pm 1.14^{* *}$ & $9.42 \pm 0.87^{* *}$ & $11.27 \pm 0.59^{* *}$ & $350.34 \pm 35.19^{* *}$ \\
Grup OLE & $26.59 \pm 0.95^{* *}$ & $8.97 \pm 0.61^{* *}$ & $10.47 \pm 0.81^{* * *}$ & $358.25 \pm 36.03^{* *}$ \\
Grup D & $23.00 \pm 1.12^{* *}$ & $5.82 \pm 0.48^{* *}$ & $8.49 \pm 0.70^{* *}$ & $475.26 \pm 47.02^{* *}$ \\
Grup T1 & $23.13 \pm 0.95^{* *}$ & $6.08 \pm 0.49^{* *}$ & $8.68 \pm 0.76^{* *}$ & $469.64 \pm 45.25^{* *}$ \\
Grup T2 & $23.68 \pm 0.97^{* *}$ & $8.13 \pm 0.26^{* *}$ & $9.81 \pm 0.73^{* *}$ & $417.30 \pm 43.63^{* *}$ \\
\hline
\end{tabular}

Tüm değerler ortalama \pm SD (n: 5) olarak ifade edildi. *P $<0.05$ Grup D'ye kıyasla, ${ }^{* *} \mathrm{P}<0.001$ Grup D'ye kıyasla LSD çoklu karşı1laştırma testlerinden önce gelen tek yönlü ANOVA. K: Kontrol; OLE: Yüksek doz OLE $\left(0.5 \mathrm{~g} \mathrm{~kg}^{-1}\right)$; D: Diyabetik; T1: Diyabetik + düşük doz OLE $\left(0.25 \mathrm{~g} \mathrm{~kg}^{-1}\right)$; T2: Diyabetik + yüksek doz OLE $\left(0.5 \mathrm{~g} \mathrm{~kg}^{-1}\right)$.

Çizelge 2 dikkate alındığında STZ indüksiyonu sonrasında diyabetik grubun serum SOD, GPx ve GST enzim aktivitelerinde kontrol grubuna kıyasla anlamlı bir düşüş olduğu anlaşılmaktadır. Daha sonra $0.25 \mathrm{~g} \mathrm{~kg}^{-1}$ ve $0.5 \mathrm{~g} \mathrm{~kg}^{-1}$ OLE ile tedaviden sonra bu enzim aktivitelerinde diyabetik gruba kıyasla anlaml bir artış olduğu görülmektedir. $0.5 \mathrm{~g} \mathrm{~kg}^{-1}$ OLE dozu, $0.25 \mathrm{~g} \mathrm{~kg}^{-1}$ OLE dozu uygulamasına kıyasla daha anlamlı sonuçlara neden olmuştur. Öte yandan lipit peroksidasyonunun belirteci olan MDA seviyesinde, STZ indüksiyonu sonrası diyabetik grupta kontrol gruba kıyasla istatistiki olarak önemli bir artış olduğu gözlenmiştir. Düşük ve yüksek doz OLE uygulaması sonrası (Grup T1 ve T2 için) MDA seviyelerinde anlamlı bir azalma olduğu gözlenmiştir. 
Biyokimyasal sonuçlarımız ve antioksidan aktivite ölçümlerimiz literatürde verilen çalışmalar ile karşılaştırılarak değerlendirilmiş ve Çizelge 3 ve 4 'te gösterilmiştir.

Çizelge 3. Mevcut çalışma ile diğer çalışmalar arasında bir karşılaştırma: STZ ile indüklenen ratlarda OLE uygulamasından sonra OLE'nin ALP, ALT ve AST seviyeleri üzerindeki etkileri

\begin{tabular}{|c|c|c|c|c|c|c|}
\hline \multirow{2}{*}{ Çözücü } & \multirow{2}{*}{$\begin{array}{l}\text { Tedavi } \\
\text { zamanı } \\
\text { (hafta) }\end{array}$} & \multirow{2}{*}{$\begin{array}{c}\text { Analiz } \\
\text { materyali }\end{array}$} & \multicolumn{3}{|c|}{ ALP/ALT/AST $\left(\mathrm{U} \mathrm{mL}^{-1}\right)$} & \multirow[b]{2}{*}{ Kaynak } \\
\hline & & & Kontrol grup & Diyabetik rat & $\begin{array}{l}\text { STZ diyabetik + } \\
\text { OLE (T2) }\end{array}$ & \\
\hline \multirow[b]{2}{*}{$\mathrm{Su}$} & \multirow[b]{2}{*}{10} & Serum & \multicolumn{3}{|c|}{ Rapor edilmemiş } & \multirow{2}{*}{$\begin{array}{r}\text { (Afify ve } \\
\text { ark., 2018) }\end{array}$} \\
\hline & & $\begin{array}{l}\text { RBC } \\
\text { lizat }\end{array}$ & - & - & - & \\
\hline $\mathrm{Su}$ & 8 & Pankreas & - & - & - & $\begin{array}{c}\text { (Al-Attar } \\
\text { veAlsalmi } \\
\text { 2019) }\end{array}$ \\
\hline Etanol & 2 & Serum & $\begin{array}{c}\text { Rapor } \\
\text { edilmemiş/ } \\
80.5 \pm 6.1 / \\
130 \pm 11.6\end{array}$ & $\begin{array}{c}\text { Rapor } \\
\text { edilmemiş/ } \\
168 \pm 23.25 / \\
205.6 \pm 8\end{array}$ & $\begin{array}{c}\text { Rapor } \\
\text { edilmemiş/ } \\
88.6 \pm 7.6 / \\
117.5 \pm 6.6\end{array}$ & $\begin{array}{c}\text { (Eidi ve } \\
\text { ark., 2009) }\end{array}$ \\
\hline \multirow{2}{*}{ Etanol } & \multirow{2}{*}{8} & Serum & \multicolumn{3}{|c|}{ Rapor edilmemiş } & \multirow{2}{*}{$\begin{array}{c}\text { (Abdel- } \\
\text { Kader ve } \\
\text { ark., 2019 }\end{array}$} \\
\hline & & Pankreas & \multicolumn{3}{|c|}{ Rapor edilmemiş } & \\
\hline Etanol & 9 & Testis & \multicolumn{3}{|c|}{ Rapor edilmemiş } & $\begin{array}{l}\text { (Soliman } \\
\text { ve ark., } \\
\text { 2019) } \\
\end{array}$ \\
\hline $\mathrm{Su}$ & 2 & Serum & $\begin{array}{r}253.08 \pm 34.46 \\
54.71 \pm 6.12 \\
157.70 \pm 18.48\end{array}$ & $\begin{array}{l}530.69 \pm 50.28 \\
108.81 \pm 11.82 \\
299.31 \pm 30.64\end{array}$ & $\begin{array}{c}502.53 \pm 46.10 \\
90.34 \pm 8.86 \\
257.18 \pm 28.93\end{array}$ & $\begin{array}{l}\text { Mevcut } \\
\text { çalışma }\end{array}$ \\
\hline
\end{tabular}

Su içinde hazırlanan yüksek doz OLE'nin, bu özütün uygulanmasından sadece iki hafta sonra diyabetik ratların karaciğer enzimlerinde, antioksidan aktivitelerinde ve lipid peroksidasyon seviyelerinde önemli değişikliklere neden olduğu gözlendi. STZ'ye bağlı hasarı tedavi etmek için her iki doz OLE verilen grupta ALT, AST ve ALP seviyeleri, Grup D'ye kıyasla istatistiki olarak önemli ölçüde azaldı ve Kontrol Grubu seviyelerine yaklaştı. Öte yandan, SOD, GPx ve GST enzim aktiviteleri artarken, MDA seviyeleri azaldı. Aynı etkiler düşük doz OLE uygulamasında da gözlendi ancak yüksek dozda elde edilen sonuçlar istatistiki olarak daha anlamlı bulundu.

STZ indüklemesi sonrası diyabetik ratların yüksek doz OLE ile tedavisinden elde edilen veriler, diyabete bağlı olarak hasar gören karaciğer dokusunda önemli bir iyileşme olduğunu gösterdi. Buna ek olarak, bu çalışmada STZ ile indüklenen diyabetik ratlara verilen yüksek doz OLE, önceki çalışmalarla tedavi süresi ve çözücü ortamı açısından karşılaştırılmış, Çizelge 3 ve 4 'te sunulmuştur. Suda hazırlanan OLE'nin karaciğer enzimleri üzerine etkisi dikkate alındığında literatürde bir çalışmaya rastlanmamıştır. $\mathrm{Bu}$ bakımdan çalışmamız özgündür. Ancak etanol içerisinde hazırlanan OLE'nin karaciğer enzimleri üzerine etkisi literatürde Eidi ve ark. tarafından araştırılmıştır (Eidi ve ark., 2009). Eidi ve ark.'nın sonuçları ile mevcut çalışmamızın sonuçları ile karşılaştırıldığında aynı tedavi süresi sonunda benzer iyileşmenin olduğu gözlenmiştir. 
Çizelge 4. Mevcut çalışma ile diğer çalışmalar arasında bir karşılaştırma: STZ ile indüklenen ratlarda OLE uygulamasından sonra OLE'nin SOD, GPx, GST aktiviteleri ve MDA düzeyleri üzerine etkileri

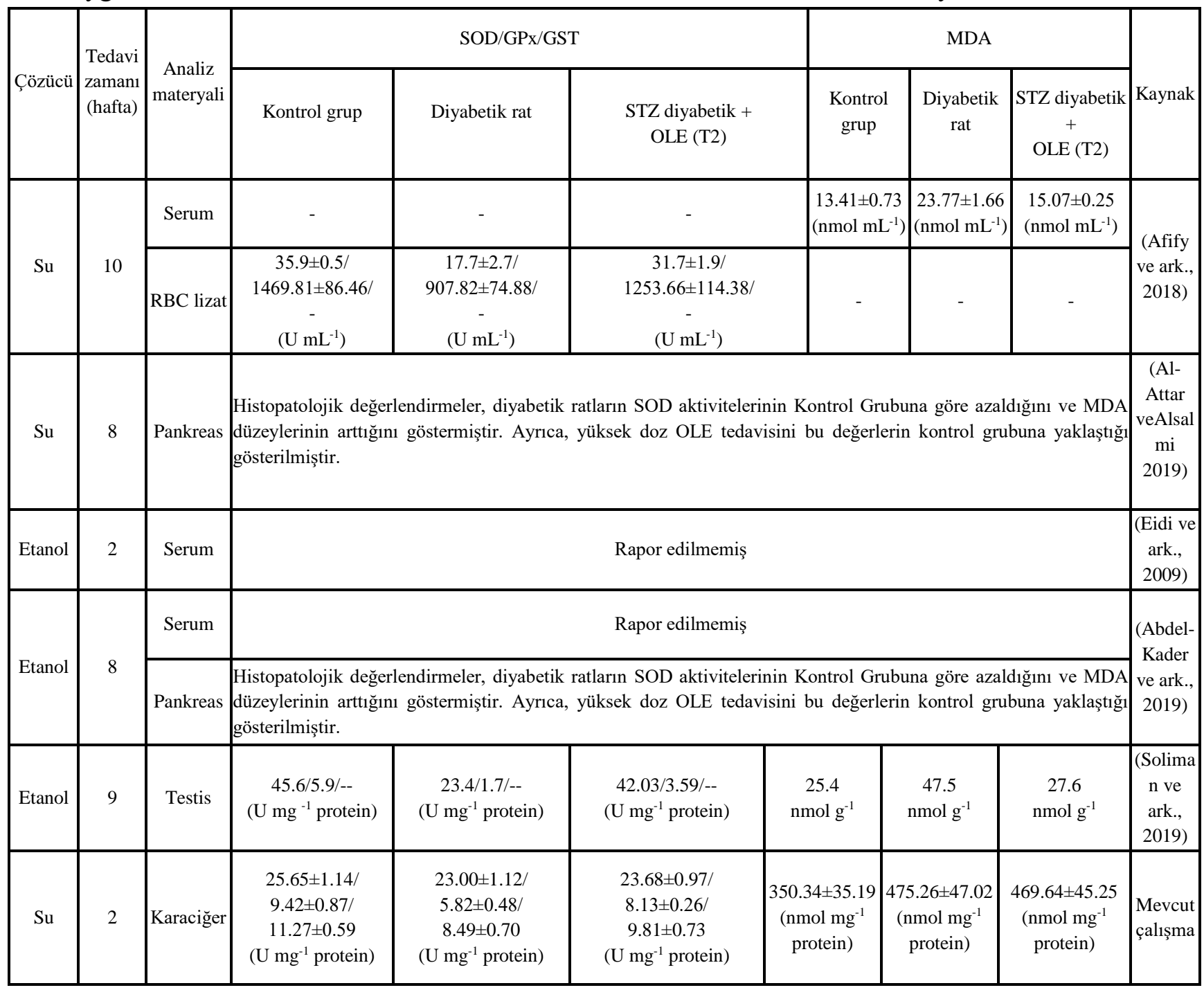

Çizelge 4'te görüldüğü gibi Afify ve ark.'nın çalışmalarında STZ ile indüklenen diyabetik ratların 10 haftalık $17.8 \mathrm{mg} \mathrm{kg}^{-1}$ OLE ile tedavisini takiben, SOD, GPx ve GST aktivitelerinde anlamlı bir artış olduğunu rapor etmişlerdir (Afify ve ark., 2018). Mevcut çalışmamızda SOD, GPx ve GST aktivitelerinde Afify ve ark.'nın elde ettiği sonuç sadece 2 haftada elde edilmiştir. Bu yönüyle mevcut çalışma avantaj sağlamaktadır. Tedavi süresindeki bu azalmanın, çalışmamızda kullandığımız zeytin yaprağı kökeninin ve özüt hazırlama metodunun farklı olmasından kaynaklanabileceği düşünülmektedir. Öte yandan Çizelge 4'te verilen çalışmalarda Soliman ve ark. ile Al-Attar ve ark.'nın çalışmaları ile mevcut çalışma sonuçlarımız karşılaştırıldığında mevcut çalışmamızın tedavi süresi bakımından avantajlı olduğu söylenebilir (Al-Attar veAlsalmi 2019).

MDA, lipit peroksidasyon sürecinin bir biyobelirtecidir (Taysi ve ark., 2008, Yoruk ve ark., 2010, Cengiz ve ark., 2016). Çizelge 4'te sunulan çalışmaların verileri, STZ ile indüklenen diyabetik ratlarda MDA düzeylerinin arttığını ortaya koymuştur. Önceki çalışmaların sonuçlarına uygun olarak, STZ'ye maruz kalma, bu çalışmada MDA düzeylerini önemli ölçüde artırmıştır. Ayrıca OLE ile tedavi edilen diyabetik ratların MDA seviyelerinde Grup D'ye göre istatistiki olarak anlamlı bir düşüş gözlenmiştir (p $<0.001)$. 
Enzimatik ve enzimatik olmayan antioksidan seviyelerinde gözlenen OLE tedavisine dayalı değişiklikler, diyabetik ratlarda iyileşme sebebini açıklayabilir (Saddala ve ark., 2013, Abdel-Kader ve ark., 2019), bu da OLE'nin reaktif oksijen türleri (ROS) aracılı oksidatif stres ve lipit peroksidasyonu ile mücadele edebildiğini göstermektedir (Rabbani ve ark., 2010). Başka bir çalışmada Soliman ve ark (Soliman ve ark., 2019) $0.5 \mathrm{~g} \mathrm{~kg}^{-1}$ OLE (\% 90 etanol içinde hazırlanmıştır) 9. haftanın sonunda SOD ve GPx aktivitelerinde artış gösterirken, 2. haftanın sonunda mevcut çalışmamızda aynı OLE dozu ile aynı artış elde edilmiştir. Mevcut çalışmamızda SOD, GPx ve GST faaliyetlerinin arttığı sürenin çok daha kısa olması açık bir avantaj olarak değerlendirilebilir. Önceki çalışmalar, hem suda hem de etil alkolde hazırlanan OLE uygulama sürelerinin mevcut çalışmaya kıyasla daha uzun olduğunu göstermiştir (Tablo 3 ve 4). Bu bakımdan çalışmamızın, Tablo 3 ve 4'te sunulan çalışmalara kıyasla kısa sürede benzer etkileri göstermesi oldukça avantajlı görülmektedir.

\section{SONUÇ}

Çalışmamızdan elde edilen veriler, zeytin yaprağının su özütünün ratlarda uygulanmasının, diyabet kaynaklı lipit peroksidasyonunu düşürdüğünü ve antioksidan savunma sistemi üzerine koruyucu etki göstererek zeytin yaprağı özütünün antioksidan aktif bileşikler içerdiğini kanıtlamıştır. Bu etki, diyabet gibi oksidatif stresle ilişkili metabolik hastalıklar üzerine OLE'nin bir antioksidan kaynağı olarak tedavi edici yönünü vurgulamaktadır. OLE'nin, STZ ile indüklenen diyabetik ratlarda diyabete bağlı olarak değișen enzimatik ve enzimatik olmayan parametreler üzerine tedavi edici etkisinin kısa olması ve serum parametre seviyelerinde anlamlı değişikliklere neden olması dikkate alındığında kullandığımız OLE'nin streptozotosin kaynaklı oksidatif stres ve lipit peroksidasyonu üzerine koruyucu bir etkisinin olabileceği sonucuna varılabilir.

\section{TEŞEKKÜR}

Yazarlar olarak çalışma alanlarının ve ekipmanların sağlanması ile ilgili destekleri için Atatürk Üniversitesi'ne teşekkür ediyoruz. Bu araştırma, kamu, ticari veya kar amacı gütmeyen sektörlerdeki finans kuruluşlarından herhangi bir hibe almadı.

\section{KAYNAKLAR}

Abdel-Kader MS, Soliman GA, Abdel-Rahman RF, Saeedan AS, Abd-Elsalam RM, \& Ogaly HA, 2019. Effect of olive leaves extract on the antidiabetic effect of glyburide for possible herb-drug interaction. Saudi Pharmaceutical Journal, 27(8), 1182-1195.

ADD, 2014. American Diabetes Association.

Afify A, El-Beltagi H, Fayed, S, \& El-Ansary A, 2018. In vivo correlation of olive leaves extract on some oxidative stress markers in streptozotocin-induced diabetes mellitus in rats. Grasas y Aceites, 69(1), 243.

Al-Attar AM, \& Alsalmi FA, 2019. Effect of Olea europaea leaves extract on streptozotocin induced diabetes in male albino rats. Saudi journal of biological sciences, 26(1), 118-128.

Baz H (2014). Streptozotocinle indüklenen diyabetli ratlar üzerinde myrtus communis 1 . Yaprağı su ekstresi etkilerinin araştırılması.

Benavente-Garcia O, Castillo J, Lorente J, \& Alcaraz M, 2002. Radioprotective effects in vivo of phenolics extracted from Olea europaea L. leaves against X-ray-induced chromosomal damage: comparative study versus several flavonoids and sulfur-containing compounds. J Med Food, 5(3), 125-135.

Benavente-García O, Castillo J, Lorente J, Ortuño A, \& Del Rio JA, 2000. Antioxidant activity of phenolics extracted from Olea europaea L. leaves. Food Chemistry, 68(4), 457-462. 
Bouaziz M, Chamkha M, \& Sayadi S, 2004. Comparative study on phenolic content and antioxidant activity during maturation of the olive cultivar Chemlali from Tunisia. Journal of Agricultural and Food Chemistry, 52(17), 5476-5481.

Bouaziz M, \& Sayadi S, 2005. Isolation and evaluation of antioxidants from leaves of a Tunusian cultivar olive tree. Eur. J. Lipid Sci. Technol., 107, 497-504.

Bradford MM, 1976. A rapid and sensitive method for the quantitation of microgram quantities of protein utilizing the principle of protein-dye binding. Analytical biochemistry, 72(1-2), 248-254.

Burtis CA, \& Ashwood ER, 1999. Tietz Textbook of Clinical Chemistry. Philadelphia, Pennsylvania W.B. Saunders Company.

Cengiz M, Ayhanci A, Kutlu HM, \& Musmul A. (2016). Potential therapeutic effects of silymarin and silymarinloaded solid lipidnanoparticles on experimental kidney damage in BALB/c mice: biochemical and histopathological evaluation. Turkish Journal of Biology, 40(4), 807-814.

Coşkunırmak D, 2018. Diyabetik ayak yarası gelişen hastaların geleneksel ve tamamlayıcı tıp uygulamalarını kullanma durumlarının incelenmesi. Adnan Menderes Üniversitesi Sağlık Bilimleri Enstitüsü.

Dawn BM, Allan DM, \& Colleen MS, 1996. Basic Medical Biochemistry a Clinical Approach. Baltimore, Maryland Lippincott Williams \& Wilkins.

Eidi A, Eidi M, \& Darzi, R 2009. Antidiabetic effect of Olea europaea L. in normal and diabetic rats. Phytotherapy Research: An International Journal Devoted to Pharmacological and Toxicological Evaluation of Natural Product Derivatives, 23(3), 347-350.

El-Amin M, Virk P, Elobeid M, Almarhoon ZM, Hassan ZK, Omer SA, . . Al-Olayan EM, 2013. Anti-diabetic effect of Murraya koenigii (L) and Olea europaea (L) leaf extracts on streptozotocin induced diabetic rats. Pak J Pharm Sci, 26(2), 359-365.

Fantel AG, 1996. Reactive oxygen species in developmental toxicity: review and hypothesis. Teratology, 53(3), 196-217.

Habig WH, Pabst MJ, and Jakoby WB, 1974. "Glutathione S-transferases the first enzymatic step in mercapturic acid formation." Journal of biological Chemistry 249(22), 7130-7139.

Jain SK, McVie R, Duett J, and Herbst JJ, 1989. "Erythrocyte membrane lipid peroxidation and glycosylated hemoglobin in diabetes." Diabetes 38(12), 1539-1543.

Jemai H, El Feki A, \& Sayadi S, 2009. Antidiabetic and antioxidant effects of hydroxytyrosol and oleuropein from olive leaves in alloxan-diabetic rats. Journal of agricultural and food chemistry, 57(19), 8798-8804.

Kritsakis A, 1998. Olive oil - From the tree to the table. Trumbull, CT (USA): Food and Nutrition Press, Inc.

Macdonald G, 2008. Harrison's Internal Medicine, 17th edition. - by A. S. Fauci, D. L. Kasper, D. L. Longo, E. Braunwald, S. L. Hauser, J. L. Jameson and J. Loscalzo. Internal Medicine Journal, 38(12), 932-932.

Paglia DE and Valentine WN, 1967. "Studies on the quantitative and qualitative characterization of erythrocyte glutathione peroxidase." The Journal of laboratory and clinical medicine 70(1), 158-169.

Pereira JA, Pereira AP, Ferreira IC, Valentao P, Andrade PB, Seabra R. . . Bento A, (2006). Table olives from Portugal: phenolic compounds, antioxidant potential, and antimicrobial activity. Journal of Agricultural and Food Chemistry, 54(22), 8425-8431.

Rabbani SI, Devi K, \& Khanam S, 2010. Protective role of glibenclamide against nicotinamide-streptozotocin induced nuclear damage in diabetic Wistar rats. Journal of pharmacology \& pharmacotherapeutics, 1(1), 18.

Saddala RR, Thopireddy L, Ganapathi N, \& Kesireddy SR, 2013. Regulation of cardiac oxidative stress and lipid peroxidation in streptozotocin-induced diabetic rats treated with aqueous extract of Pimpinella tirupatiensis tuberous root. Experimental and Toxicologic Pathology, 65(1), 15-19.

Soliman GA, Saeedan AS, Abdel-Rahman RF, Ogaly HA, Abd-Elsalam, RM, \& Abdel-Kader MS, 2019. Olive leaves extract attenuates type II diabetes mellitus-induced testicular damage in rats: Molecular and biochemical study. Saudi Pharmaceutical Journal, 27(3), 326-340.

Stadtman ER, 2004. Role of oxidant species in aging. Current Medicinal Chemistry, 11(9), 1105-1112. 
Sun Y, Oberley LW, and Li Y, 1988. "A simple method for clinical assay of superoxide dismutase." Clinical chemistry 34(3), 497-500.

Tang SY, Sivakumar M, Ng, AM-H, \& Shridharan P, 2012. Anti-inflammatory and analgesic activity of novel oral aspirin-loaded nanoemulsion and nano multiple emulsion formulations generated using ultrasound cavitation. International journal of pharmaceutics, 430(1-2), 299-306.

Taysi S, Memisogullari R, Koc M, Yazici AT, Aslankurt M, Gumustekin K, . . Ozder TH, 2008. Melatonin reduces oxidative stress in the rat lens due to radiation-induced oxidative injury. International Journal of Radiation Biology, 84(10), 803-808.

Temple NJ, 2000. Re: "Dietary flavonoid intake and risk of cardiovascular disease in postmenopausal women". American Journal of Epidemiology, 151(6), 634-635.

Tietz NW, 1995. Clinical Guide to Laboratory Tests. Philadelphia, Pennsylvania: W.B. Saunders Company.

Visioli F, Poli A, \& Gall C, 2002. Antioxidant and other biological activities of phenols from olives and olive oil. Medicinal research reviews, 22(1), 65-75.

Yanbeyi S, 1999. Aspirin ve antioksidant buthylated hydroxyanisole' ün tavşanlarda eritrosit total katalaz, süperoksit dismutaz ve glutatyon peroksidaz aktiviteleri üzerine etkileri. Ondokuz Mayıs Üni., Samsun.

Yoruk O, Gur F, Uyanik H, Yasar M, Mutlu V, Altas E, . . Taysi S, 2010. Antioxidant effects of Nigella sativa in the treatment of experimentally induced rhinosinusitis. Macedonian Journal of Medical Sciences, 3(2), 132-137. 